\title{
PEMANFAATAN MEDIA WORD SQUARE DALAM PENGEMBANGAN LEMBAR KERJA SISWA (LKS) KOMPETENSI MENULIS PENUTUR ASING
}

\author{
Hastari Mayrita \\ Dosen Universitas Bina Darma \\ Jalan Jenderal Ahmad Yani No.3 Palembang \\ Sur-el: hastari_mayrita@binadarma.ac.id
}

Article info

Article history:

Received: 10/11/2018

Revised : 16/11/2018

Accepted: 25/11/2018

\begin{abstract}
A B S T R A C T
Teaching materials is a thing that is needed by learners, especially foreign speakers who learn Indonesian. Teaching materials can also be used by Indonesian teachers to facilitate learning Indonesian language for foreign speakers. Teaching materials developed by researchers to facilitate the process of foreign speakers is LKS Bahasa Indonesia One of the teaching materials developed by researchers to facilitate the process of foreign speakers is LKS Indonesian Language people Foreign. LKS developed by researchers through this paper is LKS Writing Competency for Beginner BIPA Students. LKS developed by researchers based on word square learning model. Word square learning model is one of the contextual learning models that use media box answers. The problem in this research is how the needs of BIPA Beginner students and teachers in writing lessons that serve as learning materials development. The subject of this research is all BIPA students of Bina Darma University.
\end{abstract}

Bahan ajar suatu hal yang sangat dibutuhkan oleh peserta didik, khususnya penutur asing yang belajar bahasa. Selain itu, bahan ajar juga dapat digunakan oleh pengajar bahasa Indonesia untuk mempermudah pembelajaran bahasa Indonesia bagi penutur asing. Salah satu bahan ajar yang dikembangkan peneliti untuk mempermudah proses pembelajar penutur asing adalah LKS Bahasa Indonesia Manfaat penelitian ini untuk mempermudah proses pembelajar penutur asing adalah LKS Bahasa Indonesia Punutur Asing. LKS yang dikembangkan peneliti melalui tulisan ini adalah LKS Kompetensi Menulis untuk Siswa BIPA Pemula. LKS yang dikembangkan peneliti berbasasis model pembelajaran word square. Subjek penelitian ini adalah siswa BIPA Pemula, Universitas Bina Darma. Hasilnya adalah adanya bahan ajar menulis yang sesuai materi kebutuhan siswa BIPA, baik kebahasaannya, serta cukup menarik minat siswa BIPA. Hasil dari analisis ini akan dijadikan sebagai bahan pengembangan LKS Menulis BIPA lebih baik lagi. 


\section{JURNAL ILMIAH \\ BINA EDUKASI \\ ISSN 1979-8598 E-ISSN: 2655-8378 \\ http://journal.binadarma.ac.id/index.php/jurnalbinaedukasi \\ Vol. 11, No. 2, Desember 2018, 61-74}

\section{PENDAHULUAN}

Pada awalnya pengajaran bahasa Indonesia bagi penutur asing (BIPA) hanya sebagai wadah pelayanan beberapa pelajar berasal dari luar negeri yang ingin belajar bahasa Indonesia. Tetapi saat ini, pengajaran bahasa Indonesia mulai dilirik dan diminati oleh warga negara lain, terutama yang berada di negara asia-pasifik. Oleh karena itu, untuk berbagai kepentingan tersebut diperlukan kebijakan nasional tentang pengajaran bahasa Indonesia untuk penutur asing. Kebijakan itu seperti, kurikulum, bahan ajar, tenaga pengajar, dan sarana.

Bahan ajar merupakan suatu hal yang sangat dibutuhkan oleh peserta didik, khususnya penutur asing yang belajar bahasa Indonesia. Selain itu, bahan ajar juga dapat digunakan oleh pengajar bahasa Indonesia untuk mempermudah pembelajaran bahasa Indonesia bagi penutur asing. Salah satu bahan ajar yang dikembangkan peneliti untuk mempermudah proses pembelajar penutur asing adalah LKS Bahasa Indonesia Punutur Asing. LKS yang dikembangkan peneliti melalui tulisan ini adalah LKS Kompetensi Menulis untuk Siswa BIPA Pemula.

Menulis merupakan suatu pengetahuan dasar mengenai kompetensi menulis. Secara umum, banyak orang yang mengalami kesulitan untuk memiliki kompetensi menulis, khususnya penutur asing yang baru belajar bahasa Indonesia. Hal itu dikarenakan kegiatan menulis merupakan proses memindahkan kata atau pun konsep yang masih di kepala untuk dituangkan di dalam bentuk tulisan. Hal ini sebagaimana dikemukakan oleh, Semi (2007:14) bahwa menulis itu adalah kegiatan proses kreatif memindahkan gagasan dan lambang-lambang tulisan. Sepengamatan peneliti, penutur asing banyak mengalami kesulitan dalam melaksanakan aktivitas pembelajaran dalam kegiatan menulis. Oleh karena itu, perlu adanya sumber belajar untuk menarik minat siswa tersebut untuk belajar.

LKS merupakan sumber belajar media cetak hasil pengembangan teknologi cetak buku yang berisikan materi visual yang meliputi ringkasan materi dan latihan-latihan soal yang disertai dengan jawaban yang dikemas ke bentuk lembar jawaban atau lembar eksperimen. LKS yang dikembangkan peneliti adalah LKS yang materi ajarnya dikemas sedemikian rupa agar siswa dapat juga mempelajari materi tersebut secara mandiri. Oleh karena itu, LKS ini akan memuat materi secara terstruktur, ringkasan, dan tugas yang berkaitan dengan materi tersebut.

LKS yang dikembangkan peneliti berbasasis model pembelajaran word square. Model pembelajaran word square adalah salah model pembelajaran kontekstual yang menggunakan media kotak jawaban. Menurut Aqip (2013:31), media yang diperlukan dalam model pembelajaran word square adalah dengan membut kotak sesuai keperluan, kotak tersebut 


\section{JURNAL ILMIAH}

BINA EDUKASI

ISSN 1979-8598 E-ISSN: 2655-8378

http://journal.binadarma.ac.id/index.php/jurnalbinaedukasi

Vol. 11, No. 2, Desember 2018, 61-74

merupakan kotak jawaban dari soal pertanyaan. Jadi dalam hal ini, LKS yang dikembangkan peneliti adalah LKS yang memuat kotak jawaban.

Adapun rumusan masalah dalam penelitian ini adalah bagaimanakah kebutuhan siswa BIPA Pemula di Universitas Bina Darma terhadap bahan ajar berupa LKS yang digunakan dalam pembelajaran menulis, sehingga data yang diperoleh dapat dijadikan sebagai bahan pengembangan LKS Menulis bagi siswa BIPA Pemula.

\section{METODOLOGI PENELITIAN}

\subsection{Model Pengembangan}

Metode penelitian ini menggunakan penelitian reseacrh and development. Penelitian pengembangan ini mengadaptasi model pengembangan Jolly dan Bolitho yang dimodifikasi dengan model pengembangan Dick, Carey, dan Carey. Pemilihan dan pemodifikasian kedua model pengembangan tersebut didasari oleh beberapa alasan, yaitu: (1) model Jolly dan Bolitho merupakan model yang secara khusus digunakan untuk mengembangkan bahan ajar bahasa, (2) langkah pengembangan dalam model Jolly dan Bolitho tidak ada evaluasi sebelum penggunaan atau uji coba. Sementara, tahap uji coba merupakan salah satu komponen utama dalam penelitian pengembangan, kemudian (3) produk yang dikembangkan dalam penelitian ini merupakan produk yang akan digunakan untuk siswa BIPA Pemula di Universitas Bina Darma.

Model Jolly dan Bolitho terdiri dari beberapa langkah, yaitu (1) identifikasi kebutuhan, (2) eksplorasi kebutuhan, (3) realisasi kontekstual, (4) realisasi pedagogik, (5) pembuatan produk, (6) penggunaan produk, dan (7) evaluasi produk terhadap tujuan pembelajaran yang telah dikembangkan.

Model Dick, Carey, dan Carey terdiri dari 10 langkah, yaitu (1) identifikasi tujuan pembelajaran, (2) melakukan analisis pembelajaran, (3) analisis pembelajar dan konteks, (4) menulis tujuan pembelajaran, (5) mengembangkan instrumen penilaian, (6) mengembangkan strategi pembelajaran, (7) mengembangkan materi pembelajaran, (8) merancang dan melakukan evaluasi formatif, (9) merevisi materi pembelajaran, (10) merancang dan melakukan evaluasi sumatif (Dick, Carey, and Carey, 2005:6-7). 


\section{JURNAL ILMIAH}

BINA EDUKASI

ISSN 1979-8598 E-ISSN: 2655-8378

http://journal.binadarma.ac.id/index.php/jurnalbinaedukasi

Vol. 11, No. 2, Desember 2018, 61-74

\subsection{Subjek Penelitian}

Subjek penelitian ini adalah seluruh siswa BIPA Darmasiswa dan siswa BIPA kursus yang belajar Bahasa Indonesia di Universitas Bina Darma serta pengajar BIPA Universitas Bina Darma.

\subsection{Teknik Pengumpulan Data}

Dalam penelitian ini pengumpulan data dilakukan dengan menggunakan beberapa teknik. Teknik pengumpulan data yang digunakan dalam penelitian ini, yaitu kuesioner dan tes.

\subsubsection{Kuesioner (Angket)}

Kuesioner dalam penelitian ini diberikan kepada siswa, pengajar, dan pakar/ahli. Kuesioner siswa dan pengajar digunakan untuk memperoleh informasi tentang kebutuhan dan harapan mereka terhadap bahan ajar menulis. Kuesioner pakar/ahli digunakan untuk mendapatkan informasi mengenai kualitas produk bahan ajar yang dikembangkan, yaitu keterampilan menulis untuk kebutuhan siswa BIPA Pemula. Kuesioner yang diberikan kepada pakar/ahli dibuat berdasarkan pada tiga komponen penilaian bahan ajar, yaitu (1) komponen kelayakan isi, (2) komponen kebahasaan, (3) komponen penyajian dan kegrafikaan.

\subsubsection{Tes}

Tes digunakan untuk memperoleh informasi tentang keefektifan LKS Menulis yang dikembangkan. Tes diberikan kepada siswa BIPA Universitas Bina Darma.Tes diberikan sebelum siswa BIPA menggunakan LKS yang dikembangkan dan sesudah siswa BIPA menggunakan LKS. Bentuk tes yang akan dipersiapkan dalam penelitian ini adalah latihan menulis kalimat, menulis jawaban, dan mengasir jawaban di lembar kotak yang telah disediakan.

\subsubsection{Teknik Analisis Data}

Teknik analisis data adalah proses mencari dan menyusun secara sistematis data yang diperoleh dari hasil pengumpulan data dengan cara mengorganisasikan data, menjabarkannya, melakukan sintesa, dan membuat kesimpulan sehingga mudah dipahami diri sendiri maupun orang lain.

\subsection{Analisis Data Kuesioner}

Data yang diperoleh dari angket kebutuhan bahan ajar yang diberikan kepada peserta didik dan pendidik diolah dan dianalisis secara objektif kemudian dideskripsikan. Adapun 


\section{JURNAL ILMIAH}

BINA EDUKASI

ISSN 1979-8598 E-ISSN: 2655-8378

http://journal.binadarma.ac.id/index.php/jurnalbinaedukasi

Vol. 11, No. 2, Desember 2018, 61-74

langkah langkah analisis kuesioner kebutuhan peserta didik dan pendidik, yaitu sebagai berikut: (1) data angket diperiksa dan diklasifikasikan secara objektif; (2) data angket dianalisis dan dideskripsikan; dan (3) data angket disimpulkan.

\subsubsection{Teknik Analisis Data Angket}

Data angket yang diberikan pada mahasiswa dan dosen diolah secara objektif dan kemudian dideskripsi. Adapun langkah-langkahnya, sebagai berikut.

(1) data angket diperiksa dan diklasifikasikan secara objektif;

(2) data angket dianalisis dan dideskripsikan; dan

(3) data angket disimpulkan.

Data dari kuesioner penilaian oleh pakar/ ahli dianalisis secara deskriptif.Analisis dilakukan dengan melakukan penyekoran terhadap setiap alternatif jawaban yang dipilih pakar/ahli, kemudian dideskripsikan serta ditarik kesimpulan. Pemberian makna dan pengambilan keputusan berdasarkan nilai yang diberikan oleh pakar/ahli didasarkan pada kriteria penilaian kuesioner pakar/ahli.masing hasil penilaian komponen bahan bacaan, kemudian diberi skor berdasarkan kriteria penilaian yang telah dibuat peneliti sendiri.

Adapun kriteria penilaian oleh tim validasi ahli, sebagai berikut.

1. Kelayakan Isi/Materi
a. Kesesuaian dengan silabus BIPA
b. Kesesuaian dengan kebutuhan siswa
c. Kesesuaian dengan kebutuhan bahan ajar
d. Kesesuaian dengan kebenaran substansi
e. Kebermanfaatan penambahan wawasan pengetahuan

2. Kebahasaan
a. Keterbacaan
b. Kejelasan Informasi
c. Kesesuaian dengan kaidah bahasa Indonesia
d. Penggunaan bahasa secara efektif

3. Kegrafikan
a. Penggunaan font (ukuran dan jenis huruf)
b. Tata letak
c. Ketepatan ilustrasi gambar
d. Cover
e. Tampilan fisik 


\subsubsection{Teknik Analisis Tes}

Teknik tes diberikan dalam bentuk pretes dan postes.

\subsection{Analisis Kebutuhan}

Kebutuhan merupakan ketidaksesuaian antara apa yang ada dengan apa yang diinginkan. Menurut Suparman (2012:118), kebutuhan adalah kesenjangan keadaan saat ini dibandingkan dengan keadaan yang diharapkan atau seharusnya. Yaumi (2013:57), mengemukakan bahwa kebutuhan dalam konteks pembelajaran adalah kesenjangan pada berbagai komponen belajar dan pembelajaran termasuk yang berhubungan dengan pendidik, peserta didik, bahan, tugas, instrumen penilaian dan evaluasi yang diterapkan dalam menentukan keberhasilan pelaksanaan pembelajaran. Dalam penelitian pengembangan di bidang pembelajaran, kebutuhan-kebutuhan tersebut menjadi objek pengembangan. Oleh karena itu, analisis kebutuhan adalah langkah awal yang paling penting dan perlu dilakukan dalam penelitian pengembangan.

Analisis kebutuhan adalah kegiatan yang dilakukan untuk mengumpulkan informasi yang akan digunakan untuk mengembangan suatu pengembangan, seperti sebagai dasar bagi pengembangan materi ajar. Cunningsworth (1995, 40-42) mengemukakan bahwa analisis kebutuhan adalah suatu kegiatan untuk mempersiapkan serangkaian tujuan pembelajaran yang diarahkan bagi kebutuhan siswa, baik kekuatan ataupun kelemahan siswa dalam mempelajari sesuatu hal.

Dalam penelitian pengembangan bahan ajar, Prastowo (2008:50), mengemukakan bahwa analisis kebutuhan terdiri dari tiga tahapan, yaitu analisis terhadap kurikulum, analisis sumber belajar, dan penentuan jenis serta judul bahan ajar. Berikut tahapan-tahapan analisis kebutuhan dalam pengembangan pembelajaran.

\section{1) Analisis Kurikulum}

Langkah ini dilakukan untuk menentukan kompetensi-kompetensi yang memerlukan bahan ajar. Ada lima langkah yang mesti dilakukan dalam analisis ini, yaitu: (a) menentukan kompetensi inti yang ingin dicapai oleh peserta didik; (b) mengidentifikasi kompetensi kompetensi dasar yang diharapkan bisa dikuasai oleh peserta didik; (c) mengidentifikasi indikator pembelajaran untuk mengetahui kompetensi yang spesifik, yang nanti akan dijadikan sebagai dasar pertimbangan dalam menentukan bahan ajar yang tepat, (d) menganalisis materi pokok sebagai acuan utama dalam menyusun isi bahan ajar, dan (e) menyusun pengalaman belajar secara jelas dan operasional, sehingga langsung bisa dipraktikkan dalam kegiatan pembelajaran. 
BINA EDUKASI

ISSN 1979-8598 E-ISSN: 2655-8378

http://journal.binadarma.ac.id/index.php/jurnalbinaedukasi

Vol. 11, No. 2, Desember 2018, 61-74

\section{2) Analisis Sumber Belajar}

Langkah analisis sumber belajar dilakukan berdasarkan pada tiga kriteria, yaitu ketersediaan, kesesuaian, dan kemudahan dalam memanfaatkannya. Caranya analisis dilakukan dengan mengiventarisasi ketersediaan sumber belajar yang dikaitkan dengan kebutuhan.

\section{3) Penentuan Jenis serta Judul Bahan Ajar}

Langkah ini bertujuan untuk memenuhi salah satu kriteria bahan ajar yang baik bahwa bahan ajar harus menarik dan dapat membantu peserta didik untuk mencapai kompetensi yang diajarkan. Berdasarkan hal tersebut, maka dalam langkah ini, penyusun hendaknya menentukan dan membuat bahan ajar yang sesuai dengan kebutuhan dan kecocokan dengan kompetensi dasar yang akan dicapai oleh peserta didik; serta menetapkan jenis dan bentuk bahan ajar berdasarkan analisis kurikulum dan analisis sumber belajar.

Berdasarkan uraian di atas, maka tahap-tahap pengembangan analisis kebutuhan yang akan dilakukan peneliti, seperti tertera pada tabel berikut.

Tabel 1. Tahapan Pengembangan Analisis Kebutuhan

yang Dilakukan Peneliti

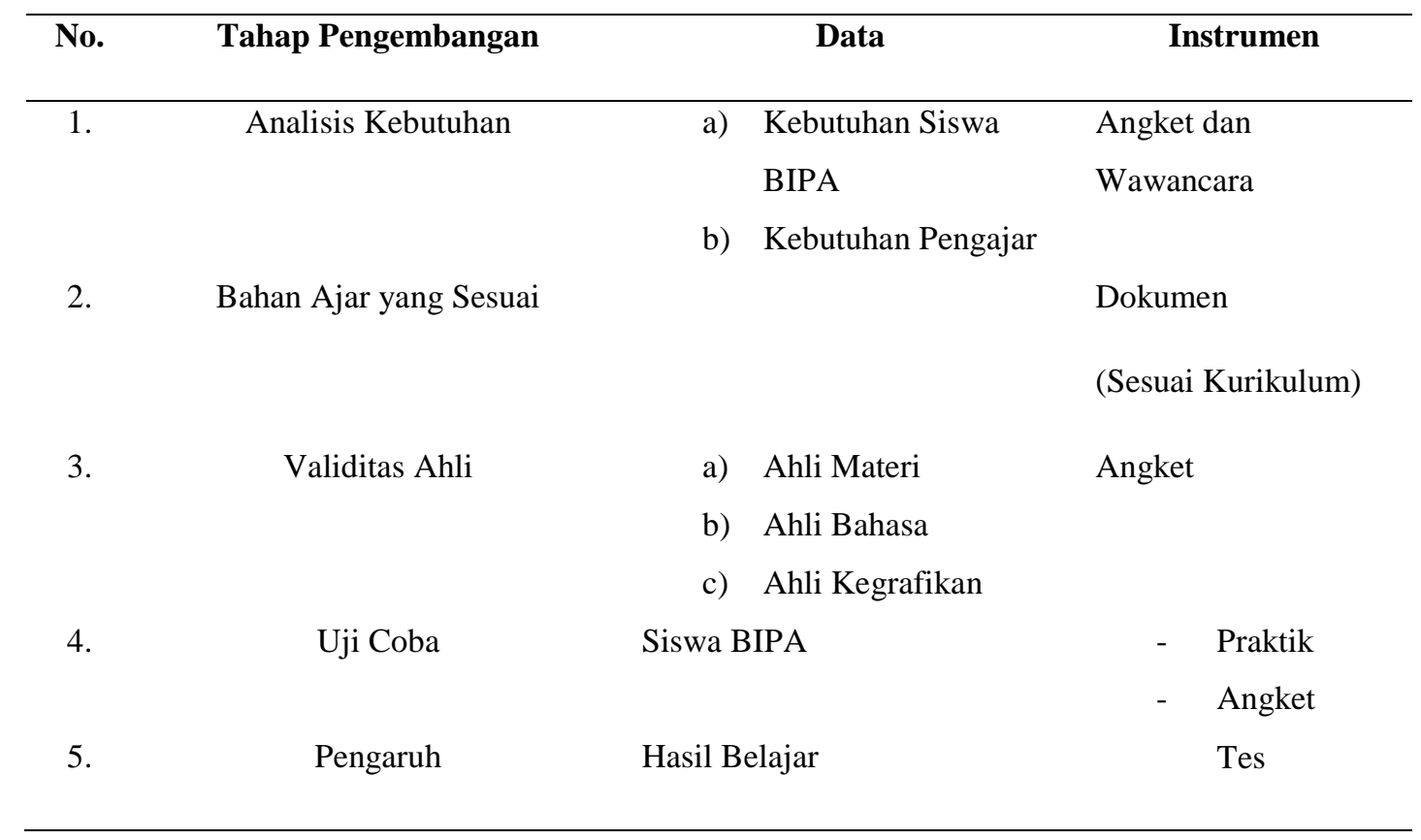


BINA EDUKASI

ISSN 1979-8598 E-ISSN: 2655-8378

http://journal.binadarma.ac.id/index.php/jurnalbinaedukasi

Vol. 11, No. 2, Desember 2018, 61-74

\subsection{Hasil Rancangan Pengembangan LKS Menulis Siswa BIPA Pemula}

\section{Bagan 1. Rancangan Pengembangan LKS BIPA}

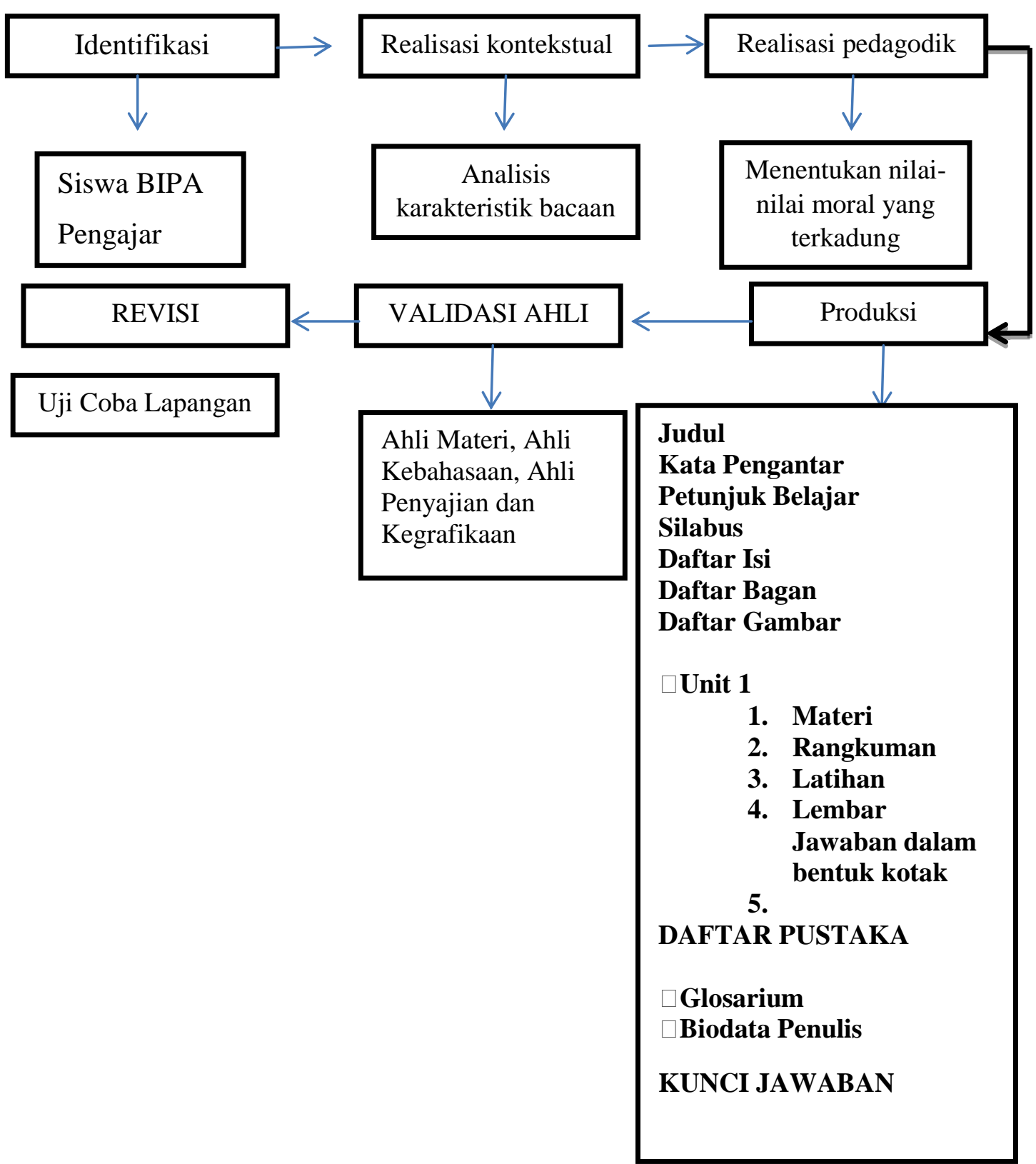




\section{JURNAL ILMIAH}

BINA EDUKASI

ISSN 1979-8598 E-ISSN: 2655-8378

http://journal.binadarma.ac.id/index.php/jurnalbinaedukasi

Vol. 11, No. 2, Desember 2018, 61-74

\section{HASIL DAN PEMBAHASAN}

Salah satu komponen penting dalam pembelajaran adalah bahan ajar. Bahan ajar merupakan perangkat ajar yang disusun secara sistematis yang isinya mengemukakan tentang bahan berupa informasi atau pun tugas-tugas yang bertujuan untuk menampilkan kompetensi yang perlu dikuasai siswa. Hal ini pun, senada dengan yang dikemukakan oleh Praswoto (2018:17) bahwa bahan ajar adalah perangkat ajar yang digunakan oleh peserta didik yang bertujuan untuk memberikan informasi berkaitan dengan kompetensi yang harus dikuasai siswa sesuai dengan tujuan perencanaan pembelajaran yang diimplementasikan.

Adapun prinsip penyusunan bahan ajar adalah harus relevansi, konsistensi, dan berkecukupan. Prinsip-prinsip dalam pemilihan materi pembelajaran meliputi prinsip relevansi, konsistensi, dan prinsip kecukupan, sebagai berikut.

a. Prinsip Relevansi

Prinsip relevansi adalah prinsip penyusunan bahan ajar yang mengedepankan materi pembelajaran yang relevan dengan pencapaian kompetensi dasar.

b. Prinsip Konsistensi

Konsistensi dalam bahan ajar adalah bahan ajar harus dapat menjadi solusi dalam pencapaian kompetensi. Konsistensi pada indikator yang harus dicapai dalam kompetensi kurikulum.

c. Prinsip Kecukupan

Prinsip kecukupan berarti materi yang diajarkan cukup memadai dan membantu siswa dalam pencapaian kompetensi.

Salah satu bahan ajar adalah LKS. Setiawan, dkk (2007:2.25), mengemukakan bahwa Lembar Kerja Siswa (LKS) merupakan materi ajar yang sudah dikemas sedemikian rupa sehingga siswa dapat diharapkan dapat mempelajari materi ajar tersebut secara mandiri. Maka dapat disimpulkan bahwa LKS adalah salah satu bahan ajar cetak yang berupa lembaranlembaran yang berisikan materi dan tugas pembelajaran yang tujuannya adalah untuk mencapai kompetensi yang diperlukan siswa.

LKS yang dikembangkan peneliti memanfaatkan model pembelajaran word square, dengan memanfaatkan media word square (kotak jawaban) dalam tugas yang dikerjakan siswa. Menurut Aqip (2013:31), media yang diperlukan dalam model pembelajaran word square adalah dengan membut kotak sesuai keperluan, kotak tersebut merupakan kotak jawaban dari soal pertanyaan. 
Media yang diperlukan dalam model word square adalah kotak. Kotak yang disiapkan sesuai dengan keperluan. Kotak berisikan soal-soal yang harus sesuai dengan kompetensi dasar yang akan diajarkan. Jumlah soal sesuai keperluan.

Adapun penyusunan LKS ini adalah dengan menyusun lembaran-lembaran kegiatan berupa kotak jawaban yang sesuai dengan contoh atau materi yang diajarkan. Kotak jawaban dapat dibuat semenarik mungkin. Banyak contoh kotak jawaban. Salah satunya, sebagai berikut.

\begin{tabular}{|c|c|c|c|c|c|c|c|c|c|}
\hline $\mathbf{P}$ & $\mathrm{E}$ & $\mathrm{S}$ & $\mathrm{A}$ & $\mathrm{N}$ & $\mathrm{A}$ & $\mathrm{K}$ & $\mathrm{A}$ & $\mathrm{L}$ & $\mathrm{W}$ \\
\hline $\mathbf{E}$ & $\mathrm{S}$ & $\mathrm{R}$ & $\mathrm{I}$ & $\mathrm{N}$ & $\mathrm{G}$ & $\mathrm{A}$ & $\mathrm{N}$ & $\mathrm{T}$ & $\mathrm{I}$ \\
\hline $\mathbf{N}$ & $\mathrm{A}$ & $\mathrm{I}$ & $\mathrm{K}$ & $\mathrm{I}$ & $\mathrm{D}$ & $\mathrm{E}$ & $\mathrm{K}$ & $\mathrm{A}$ & $\mathrm{T}$ \\
\hline $\mathbf{D}$ & $\mathrm{I}$ & $\mathrm{L}$ & $\mathrm{T}$ & $\mathrm{Y}$ & $\mathrm{K}$ & $\mathrm{E}$ & $\mathrm{C}$ & $\mathrm{I}$ & $\mathrm{L}$ \\
\hline $\mathbf{E}$ & $\mathrm{S}$ & $\mathrm{A}$ & $\mathrm{I}$ & $\mathrm{F}$ & $\mathrm{O}$ & $\mathrm{X}$ & $\mathrm{L}$ & $\mathrm{U}$ & $\mathrm{H}$ \\
\hline K & $\mathrm{E}$ & $\mathrm{M}$ & $\mathrm{P}$ & $\mathrm{P}$ & $\mathrm{E}$ & $\mathrm{N}$ & $\mathrm{D}$ & $\mathrm{E}$ & $\mathrm{K}$ \\
\hline $\mathrm{A}$ & $\mathrm{M}$ & $\mathrm{B}$ & $\mathrm{I}$ & $\mathrm{J}$ & $\mathrm{A}$ & $\mathrm{R}$ & $\mathrm{A}$ & $\mathrm{N}$ & $\mathrm{G}$ \\
\hline S & $\mathrm{P}$ & $\mathrm{A}$ & $\mathrm{S}$ & $\mathrm{I}$ & $\mathrm{R}$ & $\mathrm{O}$ & $\mathrm{D}$ & $\mathrm{A}$ & $\mathrm{I}$ \\
\hline $\mathrm{K}$ & $\mathrm{I}$ & $\mathrm{T}$ & $\mathrm{A}$ & $\mathrm{K}$ & $\mathrm{U}$ & $\mathrm{R}$ & $\mathrm{U}$ & $\mathrm{S}$ & $\mathrm{A}$ \\
\hline $\mathrm{A}$ & $\mathrm{T}$ & $\mathrm{A}$ & $\mathrm{U}$ & $\mathrm{A}$ & $\mathrm{S}$ & $\mathrm{O}$ & $\mathrm{T}$ & $\mathrm{O}$ & $\mathrm{T}$ \\
\hline
\end{tabular}

LKS yang telah dirancang digunakan oleh siswa BIPA/ Darmasiswa tingkat pemula tahun 2017 yang belajar di Universitas Bina Darma. Jumlah siswa BIPA tingkat pemula di tahun tersebut berjumlah 5 orang. Asal negara masing-masing dari Korea Selatan, Sudan, Malawi, dan Bolivia (2 0rang).

Penelitian ini baru sampai pada tahap analisis data angket. Untuk membantu pengembangan LKS Kompetensi Menulis untuk siswa BIPA Pemula di Universitas Bina Darma. Penyebaran angket diberikan kepada kelima siswa BIPA untuk memperoleh informasi tentang kebutuhan siswa BIPA tersebut dalam belajar bahasa Indonesia. Angket tersebut juga digunakan untuk melihat kekurangan, serta keunggulan dalam penggunaan LKS tersebut. LKS yang sedang berlangsung atau yang sedang dikembangkan, digunakan sebagai informasi untuk pengembangan LKS Menulis BIPA Pemula. 


\section{JURNAL ILMIAH}

BINA EDUKASI

ISSN 1979-8598 E-ISSN: 2655-8378

http://journal.binadarma.ac.id/index.php/jurnalbinaedukasi

Vol. 11, No. 2, Desember 2018, 61-74

Berdasarkan hasil analisis angket yang dianalisis secara kualitatif dan kuantitatif menggunakan uji-t dengan menggunakan SPSS 18. Adapun hasil yang diperoleh, sebagai berikut.

1) Kalayakan Isi/Materi:

Aspek yang dinilai untuk validasi isi/materi adalah aspek kesesuaian $\mathrm{KD}$, Kesesuaian dengan kebutuhan mahasiswa, kesesuaian dengan kebutuhan bahan ajar, kebenaran subtasnsi, dan manfaat untuk menambah wawasan pengetahuan, selain itu aspek ketertarikan minat siswa BIPA untuk belajar. Persentase data yang diperoleh, sebagai berikut.

Tabel. 1 Persentase Penilaian Angket Validasi Kelayakan Isi/Materi

\begin{tabular}{llll}
\hline Nilai & Predikat & Frekuensi & Persentase \\
\hline $21-25$ & Sangat baik & 4 & $80 \%$ \\
$16-20$ & Baik & 1 & $20 \%$ \\
$11-15$ & Cukup & 0 & $0 \%$ \\
$6-10$ & Kurang Baik & 0 & $0 \%$ \\
$<5$ & Tidak Baik & 0 & $0 \%$ \\
\hline
\end{tabular}

Berdasarkan hasil persentase berikut, untuk kelayakan isi LKS yang dikembangkan kategori sangat baik untuk digunakan oleh siswa BIPA Pemula Universitas Bina Darma untuk Kompetensi Menulis.

2) Kebahasaan

Aspek yang dinilai untuk validasi kebahasaan adalah keterbacaan dan kejelasan informasi, serta kesesuaian dengan kaidah bahasa Indonesia, serta penggunaan bahasa secara efektif. Persentase data yang diperoleh, sebagai berikut. 
BINA EDUKASI

ISSN 1979-8598 E-ISSN: 2655-8378

http://journal.binadarma.ac.id/index.php/jurnalbinaedukasi

Vol. 11, No. 2, Desember 2018, 61-74

Tabel. 2 Persentase Penilaian Angket Validasi Kelayakan Isi/Materi

\begin{tabular}{llll}
\hline Nilai & Predikat & Frekuensi & Persentase \\
\hline $21-25$ & Sangat baik & 4 & $80 \%$ \\
$16-20$ & Baik & 1 & $20 \%$ \\
$11-15$ & Cukup & 0 & $0 \%$ \\
$6-10$ & Kurang Baik & 0 & $0 \%$ \\
$<5$ & Tidak Baik & 0 & $0 \%$ \\
\hline
\end{tabular}

Berdasarkan hasil persentase berikut, untuk kelayakan bahasa LKS yang dikembangkan kategori sangat baik untuk digunakan oleh siswa BIPA Pemula Universitas Bina Darma untuk Kompetensi Menulis.

3) Kegrafikan

Aspek yang dinilai untuk validasi kegrafikan adalah penggunaan font (ukuran jenis dan huruf), tata letak, ketepatan ilustrasi gambar, cover, dan tampilan fisik. Persentase data yang diperoleh, sebagai berikut.

Tabel. 3 Persentase Penilaian Angket Validasi Kelayakan Isi/Materi

\begin{tabular}{cccc}
\hline Nilai & Predikat & Frekuensi & Persentase \\
\hline $21-25$ & Sangat baik & 1 & $20 \%$ \\
$16-20$ & Baik & 1 & $20 \%$ \\
$11-15$ & Cukup & 3 & $60 \%$ \\
$6-10$ & Kurang Baik & 0 & $0 \%$ \\
$<5$ & Tidak Baik & 0 & $0 \%$ \\
\hline
\end{tabular}

Berdasarkan hasil persentase berikut, untuk kegrafikan LKS yang dikembangkan kategori cukup menarik untuk digunakan oleh siswa BIPA Pemula Universitas Bina Darma untuk Kompetensi Menulis. 


\section{JURNAL ILMIAH}

BINA EDUKASI

ISSN 1979-8598 E-ISSN: 2655-8378

http://journal.binadarma.ac.id/index.php/jurnalbinaedukasi

Vol. 11, No. 2, Desember 2018, 61-74

\section{SIMPULAN}

Bahan ajar merupakan suatu hal yang sangat dibutuhkan oleh peserta didik, khususnya penutur asing yang belajar bahasa Indonesia. Selain itu, bahan ajar juga dapat digunakan oleh pengajar bahasa Indonesia untuk mempermudah pembelajaran bahasa Indonesia bagi penutur asing. Salah satu bahan ajar yang dikembangkan peneliti untuk mempermudah proses pembelajar penutur asing adalah LKS Bahasa Indonesia Punutur Asing. LKS yang dikembangkan peneliti melalui tulisan ini adalah LKS Kompetensi Menulis untuk Siswa BIPA Pemula Universitas Bina Darma. Pada tulisan ini, peneliti baru sampai pada tahap analisis data angket, yang hasilnya untuk memberikan informasi dalam membantu pengembangan LKS Keterampilan Menulis bagi siswa BIPA di Universitas Bina Darma. Adapun simpulan dari hasil analisis data angketnya adalah 1) aspek kelayakan isi sudah sangat baik, 2) aspek kebahasaan sangat baik, dan 3) aspek kegrafikan masih kategori cukup menarik minat siswa BIPA.

Oleh karena itu, berdasarkan informasi hasil analisis data. Untuk aspek kegrafikan yang ada di dalam LKS yang dikembangkan, kedepannya akan diperbaiki sampai kategori validasi aspek memenuhi kategori "sangat baik" menarik minat pembaca untuk belajar bahasa.

\section{UCAPAN TERIMA KASIH}

Ucapkan terima kasih, peneliti sampaikan kepada berbagai pihak yang terlibat, khususnya:

1) Universitas Bina Darma. Melalui lembaga DRPM Universitas Bina Darma, atas bantuan sarana yang disediakan untuk kegiatan penelitian, sehingga penelitian ini berjalan dengan baik;

2) terima kasih juga kepada lembaga BIPA Universitas Bina Darma, atas kerja samanya dalam hal pemberian izin penelitian dan informasi data siswa BIPA di Universitas Bina Darma;

3) selain itu, peneliti juga mengucapkan terima kasih banyak kepada 2 orang tim mahasiswa Program Studi Pendidikan Bahasa Indonesia, FKIPB, Universitas Bina Darma, yang terlibat dalam penelitian ini, dari membantu menyebarkan angket ke responden, serta mengelola data penelitian. 


\section{JURNAL ILMIAH}

BINA EDUKASI

ISSN 1979-8598 E-ISSN: 2655-8378

http://journal.binadarma.ac.id/index.php/jurnalbinaedukasi

Vol. 11, No. 2, Desember 2018, 61-74

\section{DAFTAR PUSTAKA}

Aqib, Zainal. (2013). Model-Model, Media, dan Strategi Pembelajaran Kontekstual. Bandung: Yrama Widya.

Cunningsworth, Alan. (1995). Choosing Your Course-Book. Oxford: Heilnemann.

Dick, Walter and Lou Carey, James O. Carey. (2005). The Systematic Design of Instruction. London: Pearson .

Prastowo, Andi. (2011). Panduan Kreatif Membuat Bahan Ajar Inovatif. Yogyakarta: Diva Press.

Semi, M. Atar. (2007). Dasar-Dasar Keterampilan Menulis. Bandung: Angkasa Bandung.

Setiawan, Denny, dkk. (2007). Pengembangan Bahan Ajar. Jakarta: Universitas Terbuka.

Suparman, M. Atwi. (2012). Panduan Para pengajar \& Inovator Pendidikan: Desain Instruksional Modern. Jakarta: Erlangga

Yaumi, Muhammad. (2013). Prinsip-Prinsip Desain Pembelajaran. Jakarta: Kencana Media Group. 